\title{
Studi Formulasi Sediaan Lip Balm Ekstrak Kayu Secang (Caesalpinia sappan L.) dengan Variasi Beeswax
}

\author{
Yani Ambari ${ }^{1 *}$, Fitra Nanda Dwi Hapsari ${ }^{2}$, Arista Wahyu Ningsih ${ }^{3}$, lif Hanifa Nurrosyidah ${ }^{4}$, Butet Sinaga ${ }^{5}$ \\ 1,2,3,5 Program Studi S1 Farmasi STIKES Rumah Sakit Anwar Medika, Sidoarjo, Indonesia \\ ${ }^{4}$ Program Studi DIII Farmasi STIKES Rumah Sakit Anwar medika, Sidoarjo, Indonesia
}

*E-mail: yaniambari87@gmail.com

\begin{abstract}
Lips are one part of the skin that needs protection so that the moisture of the lips is maintained. As a result of poor protection functions the lips become dry, cracked, and the color of the lips become dull. Lip balm is a preparation that is applied to the lips to prevent dry lips and protect from the adverse environmental effects. The physical quality of lip balm is a factor that must be met before lip balm preparations are marketed to consumers. Choosing the right basis will determine the quality of violence so that it can be accepted by the community, because the base is the main form of lip balm preparation. Beeswax has good binding properties, which helps to produce a homogeneous mass. In this research, the active ingredient used is sappan wood because it contains brazilein compounds which can be used as natural dyes and antioxidants. This research is an experimental research using lip balm formulation using beeswax 5\%, 10\% and 15\%. The purpose of this study was to find out the right formulation of lip balm preparations with active ingredients of secang wood extract (Caesalpinia sappan L.), know the physical stability of lip balm preparations with the active ingredient of secang wood extract (Caesalpinia sappan L.), find out the appropriate base concentration, to get a quality lip balm preparation (according to pharmaceutical standards). The results of the study have found a good formula with physical characteristics that fit the specified specifications include, stability monitoring, $\mathrm{pH}$ measurement, homogeneity testing, irritation testing, preference test (Hedonic test) and cycling test. The right formula can be in formula 1 with a beeswax concentration of 5\% produce a color texture, aroma, has a value of good adhesion and dispersion, $\mathrm{pH}$ according to lip $\mathrm{pH}$, non-irritating, homogeneous preparations, most preferred by respondents and stable during storage. A good base concentration of 5\% base in formula 1 because it produces a semi-dense and very smooth lip balm texture.
\end{abstract}

Keywords: Lip balm, Beeswax, Lips, Caesalpinia sappan

\begin{abstract}
ABSTRAK
Bibir merupakan salah satu bagian kulit yang membutuhkan perlindungan agar kelembaban bibir tetap terjaga. Akibat dari fungsi perlindungan yang buruk bibir menjadi kering, pecah-pecah, dan warna bibir menjadi kusam. Lip balm adalah sediaan yang diaplikasikan pada bibir untuk mencegah bibir kering dan melindungi dari efek lingkungan yang buruk. Kualitas fisik lip balm merupakan faktor yang harus dipenuhi sebelum sediaan lip balm dipasarkan ke konsumen. Pemilihan basis yang tepat akan menentukan kualitas kekerasan sehingga dapat diterima oleh masyarakat, karena basis merupakan pembentuk utama dari sediaan lip balm. beeswax mempunyai sifat sebagai pengikat yang baik, dimana membantu untuk menghasilkan massa yang homogen. Pada penelitian ini bahan aktif yang digunakan yaitu kayu secang karena mengandung senyawa brazilein yang bisa sebagai pewarna alami dan antiokasidan.. Penelitian ini merupakan penelitian eksperimental formulasi sediaan lip balm dengan menggunakan beeswax 5\%, 10\% dan 15\%. Tujuan penelitian ini Mengetahui formulasi yang tepat sediaan lip balm dengan bahan aktif ekstrak kayu secang (Caesalpinia sappan L.), mengetahui stabilitas fisik sediaan lip balm dengan bahan aktif ekstrak kayu secang (Caesalpinia sappan L.), mengetahui konsentrasi basis yang sesuai, untuk mendapatkan sediaan lip balm yang berkualitas (sesuai standart farmasi). Hasil penelitian telah didapatkan formula yang bagus dengan karakteristik fisik yang sesuai dengan spesifikasi yang telah ditentukan meliputi pengamatan stabilitas, pengukuran $\mathrm{pH}$, pengujian homogenitas, pengujian iritasi, pengujian kesukaan (Hedonic test) dan pengujian cycling test. formula yang tepat di dapat pada formula 1 dengan konsentrasi beeswax 5\% menghasilkan tekstur warna, aroma, memiliki nilai daya lekat dan daya sebar yang baik, $\mathrm{pH}$ sesuai terhadap $\mathrm{pH}$ bibir, tidak mengiritasi, sediaan homogen, paling banyak
\end{abstract}


disukai oleh responden dan stabil selama penyimpanan. Konsentrasi basis yang baik yaitu basis $5 \%$ pada formula 1 karena menghasilkan tekstur lip balm semi padat dan sangat halus.

Kata kunci : Lip balm, Beeswax , Bibir, Caesalpinia sappan

\section{Pendahuluan}

Kosmetika adalah bahan atau sediaan yang dimaksud untuk digunakan pada bagian luar tubuh manusia (rambut, kuku dan organ genital bagian luar) atau gigi dan mukosa mulut terutama untuk membersihkan, mengharumkan, mengubah penampilan dan memelihara tubuh pada kondisi baik [1]. Kosmetik dekoratif adalah kosmetik yang diperlukan untuk merias atau menutup cacat pada kulit sehingga menghasilkan penampilan lebih menarik serta menimbulkan efek psikologis yang baik, seperti percaya diri. Terdapat beberapa contoh dari kosmetik dekoratif yaitu lipstik, bedak, dan eye-shadow. Kosmetik perawatan kulit yaitu untuk perawatan kulit yang diperlukan untuk merawat kebersihan dan kesehatan kulit, diantaranya yaitu pembersih, pelembab dan kosmetik pelindung [2].

Bibir merupakan salah satu bagian kulit yang membutuhkan perlindungan agar kelembaban bibir tetap terjaga. Hal ini disebabkan karena bibir tidak memiliki folikel rambut dan kelenjar keringat serta lapisan korneum yang sangat tipis dibanding kulit biasa yakni terdiri 3-4 lapisan [3]. Karena kulit bibir lebih tipis, bibir menjadi lebih mudah luka dan mengalami perdarahan. Bibir merupakan bagian kulit yang paling sensitif terhadap cuaca panas dan dingin yang bisa menyebabkan kerusakan pada bibir yaitu, bibir menjadi kering dan pecah-pecah [4].

Selain cuaca panas dan dingin, paparan sinar UV matahari serta dapat merusak sel keratin bibir yang berfungsi melindungi bibir. Sel keratin yang rusak akan terkelupas sehingga bibir terlihat pecah-pecah, bibir menjadi kering dan warna bibir menjadi kusam. Akibat dari fungsi perlindungan yang buruk, bibir sangat rentan terhadap pengaruh lingkungan serta berbagai produk perawatan kesehatan, kosmetik, dan produk perawatan kulit lainnya yang dapat menyebabkan kerusakan kulit yaitu bibir menjadi kering, pecah-pecah dan warna bibir menjadi kusam. Selain kusam, bibir yang pecah-pecah dapat menimbulkan rasa nyeri, tidak nyaman dipandang serta kulit bibir semakin tidak sehat [5]. Untuk memperbaiki kondisi bibir tersebut diperlukan sediaan kosmetik lip balm yang dapat merawat bibir.

Lip balm adalah sediaan yang diaplikasikan pada bibir untuk mencegah bibir kering dan melindungi dari efek lingkungan yang buruk. Lip balm digunakan sebagai langkah awal untuk mencegah terjadinya masalah bibir. Lip balm merupakan sediaan kosmetik yang diaplikasikan pada bibir dengan komponen utama seperti lilin, lemak dan minyak dengan tujuan untuk mencegah terjadinya kekeringan pada bibir dengan meningkatkan kelembaban bibir dengan cara membentuk lapisan minyak yang tidak dapat bercampur pada permukaan bibir. Lapisan yang terbentuk oleh lip balm merupakan lapisan pelindung bibir dari lapisan luar [4].

Kualitas fisik lip balm merupakan faktor yang harus dipenuhi sebelum sediaan lip balm dipasarkan ke konsumen. Dalam formulasi lip balm terdapat basis utama, antara lain lilin yang memberikan kekakuan. Lilin yang banyak digunakan pada sediaan kosmetik yaitu beeswax. Beeswax adalah jenis lilin yang sering digunakan pada sediaan kosmetik, beeswax mempunyai sifat sebagai pengikat yang baik, dimana membantu untuk menghasilkan massa yang homogen. Beeswax mempunyai sifat retensi minyak yang baik dimana berperan sebagai pengikat untuk bergabung bersama komponen yang berbeda dalam formulasi dan dapat memperbaiki struktur lip balm.

Kayu secang (Caesalpinia sappan L) memiliki kandungan kimia diantaranya yaitu asam galat, tanin, resin, resorsin, brazilin, brazilein, d- $\alpha$-phellandrene, oscimene, dan minyak atsiri [6]. Brazilein termasuk ke dalam golongan flavonoid sebagai homoisoflavonoid. Pigmen brazilein dapat berfungsi sebagai analgesic, antiinflamasi antioksidan, antidiabetes, antimikroba. Kayu secang memiliki banyak manfaat bagi kesehatan yaitu sebagai antivirus, antikanker, antiinflamasi, antitumor, antidiabetik, antiinflamasi. Dari uraian diatas penulis tertarik untuk melakukan penelitian studi formulasi sediaan lip balm menggunakan ekstrak kayu secang dengan menggunakan konsentrasi beeswax yaitu 5\%, $10 \%$, dan $15 \%$. Tujuan dari penelitian ini yaitu mengetahui formulasi sediaan lip balm dengan bahan aktif ekstrak kayu secang (Caesalpinia sappan L.) dan stabilitas fisik sediaan lip balm dengan bahan aktif ekstrak kayu secang (Caesalpinia sappan L.).

\section{Bahan dan Metode}

\subsection{Alat dan Bahan Penelitian}

Bahan yang digunakan adalah serbuk Kayu Secang (Caesalpinia sappan L) yang didapat dari Materia Medika 
Batu Malang, beeswax, kaolin, olive oil, metil paraben, setil alkohol, dan esence strawberry, $\mathrm{HCl} 2 \mathrm{M}, \mathrm{NaOH} 2 \mathrm{M}$, larutan Mayer Dragendrof, anhidrat asetat, sulfat pekat,n-heksana, asam asetat anhidrat, $\mathrm{H} 2 \mathrm{SO} 4$ pekat.

Alat yang digunakan adalah timbangan digital, sendok tanduk, cawan porselin, mortir dan stamper, beaker glass, sudip, batang pengaduk, pot lipbalm, penangas air, penjepit kayu, pipet tetes, kertas saring, tabung reaksi dan raknya, $\mathrm{pH}$ universal rotary ovaporator, alat $s S$ analyzer, alat uji daya sebar, alat uji daya lekat.

\subsection{Metode Ekstraksi Kayu Secang}

Ditimbang serbuk secang sebanyak 1000 gram dimasukkan kedalam wadah berwarna gelap dan ditambahkan etanol 96\% sebanyak 7,5 liter hingga simplisia terendam sempurna. Simplisia diaduk rata kemudian bejana ditutup rapat. Proses maserasi dilakukan 5x24 jam dengan beberapa kali pengadukan dan diletakkan ditempat yang terhindar dari sinar matahari. Maserat yang dihasilkan kemudian disaring menggunakan kertas saring dengan bantuan pompa vacum untuk memisahkan dari filtratnya. Filtrat yang dihasilkan diuapkan menggunakan rotary evaporator dengan menggunakan suhu $40^{\circ} \mathrm{C}$.

\subsection{Skrinning Fitokimia Ekstrak Kayu Secang}

\section{Identifikasi Senyawa Flavonoid}

Identifikasi senyawa flavonoid pada ekstrak kayu secang yaitu sampel diambil sebanyak $5 \mathrm{ml}$ ditambahkan $0,05 \mathrm{~g}$ serbuk $\mathrm{Mg}$ dan $1 \mathrm{~mL} \mathrm{HCl}$ pekat, kemudian dikocok kuat. Uji positif ditunjukkan dengan terbentuknya warna merah kuning atau jingga [7].

\section{Identifikasi Senyawa Alkaloid}

Identifikasi senyawa alkaloid pada ekstrak kayu secang yaitu Ekstrak sebanyak $1 \mathrm{ml}$ dimasukan kedalam tabung reaksi, kemudian beberapa tetes larutan reagen Mayer, Wagner, Dragendorf ditambahkan kedalam tabung reaksi yang telah diisi ekstrak kayu secang. Terbentuk endapan pada sampel uji menunjukkan bahwa sampel mengandung alkaloid. Endapan putih terbentuk dengan penambahan reagen Mayer, endapan berwarna coklat terbentuk dengan penambahan reagen Wagner dan terbentuknya endapan merah dengan reagen Dragendorf [8].

\section{Identifikasi Senyawa Saponin}

Identifikasi senyawa saponin pada ekstrak kayu secang yaitu Metode Forth dipilih untuk mengidentifikasi senyawa ini dengan cara yaitu $2 \mathrm{~mL}$ sampel dimasukkan ke dalam tabung reaksi, kemudian ditambahkan $10 \mathrm{~mL}$ aquades, lalu dikocok ke dalam selama 30 detik. Apabila terbentuk busa yang tidak hilang selama 30 detik menunjukkan adanya saponin.

\section{Identifikasi Senyawa Terpenoid}

Identifikasi senyawa terpenoid dalam ekstrak kayu secang dilakukan dengan cara ekstrak yang diperoleh diambil sedikit dan dikeringkan pada papan tetes, ditambahkan 3 tetes anhidrida asetat dan 1 tetes asam sulfat pekat. Adanya senyawa golongan terpenoid akan ditandai dengan timbulnya warna merah [9].

\section{Identifikasi Senyawa Triterpenoid}

Identifikasi senyawa triterpenoid dalam ekstrak kayu secang dilakukan dengan cara ekstrak sampel dilarutkan dalam $1 \mathrm{ml} \mathrm{n}$-heksana, ditambah dengan 0,5 $\mathrm{ml}$ asam asetat anhidrat. Campuran tersebut ditetesi dengan $2 \mathrm{ml} \mathrm{H} 2 \mathrm{SO} 4$ pekat pada dinding tabung. Jika hasil yang diperoleh berupa cincin kecoklatan pada perbatasan dua pelarut menunjukkan adanya triterpenoid.

\subsection{Rancang Formulasi Sediaan Lip Balm Esktrak Kayu Secang}

Formulasi lip balm ekstrak kayu secang menggunakan tiga formulasi yang berbeda, yang membedakan antara tiga formulasi tersebut yaitu pada konsentrasi basisnya yaitu beeswax. Formulasi sediaan lip balm ekstrak kayu secang dapat dilihat pada tabel 1.

Tabel 1. Formulasi Sediaan Lip Balm Esktrak Kayu Secang

\begin{tabular}{|c|c|c|c|c|}
\hline Bahan & Fungsi & Formula 1 & Formula 2 & Formula 3 \\
\hline Ekstrak kayu secang & Bahan aktif & $5 \%$ & $5 \%$ & $5 \%$ \\
\hline Beeswax & Basis & $5 \%$ & $10 \%$ & $15 \%$ \\
\hline Setil alkohol & Pengental & $10 \%$ & $10 \%$ & $10 \%$ \\
\hline Metil paraben & Pengawet & $0,03 \%$ & $0,03 \%$ & $0,03 \%$ \\
\hline Olive oil & Emolien & $5 \%$ & $5 \%$ & $5 \%$ \\
\hline Essence strawberry & Pengaroma & $1 \%$ & $1 \%$ & $1 \%$ \\
\hline
\end{tabular}




\subsection{Pembuatan Sediaan Lip Balm Ekstrak Kayu Secang}

Pembuatan sediaan lip balm dengan bahan aktif ekstrak kayu secang adalah disiapkan mortir panas terlebih dahulu, selanjutnya beeswax dan setil alkohol dimasukkan cawan penguap dan dilebur dipenangas air dengan suhu $70^{\circ} \mathrm{C}$. Bahan yang sudah dilebur dipindahkan ke mortir panas dan diaduk hingga homogen. metil paraben dimasukkan sedikit demi sedikit dan diaduk hingga homogen. Kaolin dimasukkan sedikit demi sedikit dan diaduk hingga homogen. Selanjutnya olive oil dan ekstrak kental kayu secang dimasukkan ke dalam basis dan diaduk hingga homogen. Selanjutnya dimasukkan esence strawberry dan diaduk hingga homogen.

\subsection{Stabilitas Fisik Lip Balm Ekstrak Kayu Secang}

Uji stabilitas fisik pada sediaan lip balm dengan bahan aktif ekstrak kayu secang (Caesalpinia sappan L) menggunakan metode cycling test untuk mengetahui kestabilan sediaan dengan pengaruh variasi suhu selama waktu penyimpanan. Sediaan disimpan pada kulkas dengan suhu $4^{\circ} \mathrm{C}$ selama 24 jam dan dilanjutkan dengan menyimpan sediaan pada oven dengan suhu $40^{\circ} \mathrm{C}$ selama 24 jam. Pengujian dilakukan sebanyak 6 siklus dan diamati terjadinya perubahan fisik dari sediaan pada awal dan akhir pengujian yang meliputi organoleptik, homogenitas, dan $\mathrm{pH}$. Evaluasi yang dilakukan meliputi uji organoleptis, uji pH, uji homogenitas, uji daya sebar dan uji daya lekat.

\section{Uji Organoleptis}

Organoleptis adalah suatu pengujian dengan menggunakan indera manusia sebagai alat utama untuk pengukuran daya penerimaan terhadap suatu sediaan. Macam-macam uji yang dilakukan yaitu dengan melihat warna, rasa, bau, dan bentuk.

\section{Uji pH}

Pengukuran $\mathrm{pH}$ dilakukan dengan menggunakan alat Indikator $\mathrm{pH}$ Universal, dan masing-masing formula direplikasi 3 kali.Universal Indikator $\mathrm{pH}$ dicelupkan kedalam sediaan lip balm dan dibiarkan beberapa detik, lalu warna pada kertas dibandingkan dengan pembanding pada kemasan.

\section{Uji Homogenitas}

Masing-masing sediaan lip balm dengan bahan aktif ekstrak kayu secang diperiksa homogenitasnya dengan cara mengoleskan 1 gram sediaan pada kaca objek, lalu diamati partikel yang kasar dengan cara diraba dan sediaan harus menunjukkan susunan yang homogen dan tidak terlihat adanya butir-butir kasar [10].

\section{Uji Daya Sebar}

Sampel sediaan lip balm ditimbang sebanyak 0,5 gram diletakkan di atas alat uji daya sebar yang berupa lempengan kaca beralaskan kertas skala,tutup dengan kaca pasangannya (yang sebelumnya sudah ditimbang), dan dibiarkan selama 1 menit, diukur diameter penyebaran lip balm dengan cara mengukur dari berbagai sisi dan dihitung rata-ratanya, diulang sebanyak 3 kali replikasi dengan cara yang sama dengan penambahan beban secara berkala $(50 \mathrm{~g}, 100 \mathrm{~g}, 150$ g, $200 \mathrm{~g})$ [11].

\section{Uji Daya Lekat}

Sampel sediaan lip balm ditimbang sebanyak 0,25 gram, lalu diletakkan diatas gelas objek. Kedua gelas objek ditempelkan sampai menyatu. Kemudian diletakkan dengan beban seberat $1 \mathrm{~kg}$ selama 5 menit setelah itu dilepaskan, lalu diberi beban 80 gram dan dicatat waktunya hingga kedua gelas obyek tersebut terlepas. Replikasi dilakukan sebanyak 3 kali.

\section{Uji Iritasi}

Teknik yang dilakukan pada uji iritasi ini adalah uji tempel terbuka (open patch) pada bagian lengan bawah bagian dalam terhadap 10 panelis yang bersedia dan menulis surat pernyataan. Uji tempel terbuka dilakukan dengan mengoleskan sediaan pada lokasi lekatan dengan luas tertentu $(2,5 \times 2,5 \mathrm{~cm})$, dibiarkan terbuka dan diamati apa yang terjadi. Uji ini dilakukan sebanyak 3 kali sehari selama dua hari berturut-turut [2]. Kriteria inklusi uji iritasi meliputi : wanita berusia 20-30 tahun, sehat jasmani dan rohani, tidak memiliki riwayat penyakit alergi, dan menyatakan kesediaanya untuk dijadikan responden [8]. Reaksi yang diamati adalah terjadinya eritema, papula, vesikula atau edema.

\section{Uji Kelembaban Sediaan}

Pengujian efektivitas sediaan dilakukan terhadap 9 orang panelis. Pengujian dilakukan pada daerah bibir. Pengelompokan dibagi menjadi :

a. Kelompok I : 3 orang panelis menggunakan formula 1

b. Kelompok II: 3 orang panelis menggunakan formula 2

c. Kelompok III: 3 orang panelis menggunakan formula 3

Pengujian dengan membandingkan keadaan bibir sebelum dan sesudah pemakaian sediaan dengan nilai parameter kelembaban. Semua panelis diukur terlebih dahulu kondisi kelembaban bibir awal menggunakan alat skin analyzer. Sediaan lip balm dioleskan pada bibir panelis lalu dibiarkan hingga 12 jam, dan pengecekan kondisi kelembaban bibir dilakukan selama 12 jam sekali sebelum dan sesudah pemakaian lip balm. Pengukuran kondisi bibir dilakukan setiap hari selama 7 hari dengan pemberian sediaan lip balm setiap hari secara rutin pagi dan malam hari. 


\section{Hasil dan Pembahasan}

Proses ekstraksi kayu secang menggunakan metode maserasi. Maserasi merupakan proses penyarian dengan cara merendam sampel menggunakan pelarut sampai dengan beberapa kali pengocokan atau pengadukan pada suhu ruang [7]. Ekstraksi dilakukan menggunakan pelarut etanol. Pemilihan pelarut etanol, karena etanol $96 \%$ memiliki sifat yang mampu melarutkan hampir semua zat, baik yang bersifat polar maupun non polar [11]. Berdasarkan dari hasil penelitian di dapatkan nilai rendemen ekstrak kayu secang sebesar 8,2\% dengan berat 82 gram. Semakin besar rendemen yang dihasilkan, maka semakin efisien perlakuan yang diterapkan dengan tidak mengesampingkan sifat-sifat lain. Berdasarkan hasil rendemen dapat diasumsikan bahwa komponen bioaktif yang terkandung dalam kayu secang sebesar $8,2 \%$. Nilai rendemen yang tinggi menunjukkan banyaknya komponen bioaktif yang terkandung di dalamnya. Ekstrak kental kayu secang yang dihasilkan berwarna coklat pekat, tidak berasa, dan bau khas kayu secang.

Uji skrinning fitokimia dilakukan untuk melihat kandungan senyawa kimia yang terkandung di dalam tanaman kayu secang. Skrinning fitokimia dilakukan untuk mengetahui kandungan senyawa fitokimia pada ekstrak kayu secang (Caesalpinia sappan L.) dan untuk mengetahui senyawa kayu secang yang bisa berfungsi sebagai pewarna alami dan sebagai antioksidan.Hasil dari uji skrinning fitokimia menunjukkan bahwa tanaman kayu secang mengandung senyawa brazilein, terpenoid, triterpenoid, saponin, alkaloid dan flavonoid. Hasil uji skrinning dapat dilihat pada Tabel 2.

Senyawa flavonoid merupakan senyawa yang umumnya terdapat pada tumbuhan berpembuluh, terikat pada glukosida dan aglikon flavonoid [7]. Hasil yang diperoleh dari skrinning fitokimia flavonoid yaitu dengan terbentuknya warna merah. Suatu sampel mengandung senyawa flavonoid jika terbentuk warna merah, kuning atau jingga [7]. Berdasarkan hal tersebut dapat disimpulkan bahwa ekstrak kayu secang Caesalpinia sappan L.) mengandung senyawa flavonoid. Hasil yang diperoleh dari skrinning fitokimia brazilein yaitu dengan terbentuknya warna merah. Suatu sampel mengandung senyawa brazilein jika terbentuk warna merah, kuning atau jingga [7]. Berdasarkan hal tersebut dapat disimpulkan bahwa ekstrak kayu secang (Caesalpinia sappan L.) mengandung senyawa brazilein. Dengan adanya senyawa brazilein pada kayu secang maka kayu secang bisa digunakan sebagai pewarna alami.

Tabel 2. Hasil Uji Skrinning Fitokimia Kayu Secang (Caesalpinia sappan L)

\begin{tabular}{cccc}
\hline No & Senyawa Kimia & Hasil & Keterangan \\
\hline 1. & Alkaloid & + & Terbentuk warna merah \\
2 & Flavonoid & + & Terbentuk endapan \\
3. & Terpenoid & + & Terbentuk busa \\
4. & Triterpenoid & + & Terbentuknya warna merah \\
5. & Saponin & + & Terbentuknya cincin kecoklatan \\
6. & Brazilein & + & Perubahan warna menjadi semakin pekat \\
\hline
\end{tabular}

Basis yang digunakan dalam penelitian ini adalah beeswax. Basis lilin sangat berperan penting terhadap kekerasan lip balm. Beeswax sangat sering digunakan dalam penelitian lip balm untuk meningkatkan kekerasan. Batas maksimum penggunaan beeswax dalam suatu formula adalah 5-20\% [12]. Konsentrasi pada kayu secang 5\% karena pada penelitian Neswati (2018) tentang ekstraksi komponen bioaktif kayu secang sebagai antioksidan, ekstrak kayu secang memiliki kadar antioksidan tertinggi pada konsentrasi $5 \%$.

Uji stabilitas sediaan dilakukan bertujuan untuk mengetahui stabil atau tidaknya sediaan lip balm ekstrak kayu secang selama penyimpanan. penyimpanan. Metode stabilitas yang digunakan adalah uji stabilitas dipercepat. Uji stabilitas fisik ini dilakukan dengan metode cycling test. Pengujian ini dimaksudkan untuk mendapatkan informasi yang diinginkan pada waktu sesingkat mungkin dengan cara menyimpan sampel pada kondisi yang dirancang untuk mempercepat terjadinya perubahan yang biasanya terjadi pada kondisi normal. Stabilitas didefinisikan sebagai kemampuan suatu produk obat atau kosmetik untuk bertahan dalam spesifikasi yang diterapkan sepanjang periode penyimpanan dan penggunaan untuk menjamin identitas, kekuatan, kualitas. Sediaan dapat dikatakan stabil apabila suatu sediaan yang masih berada dalam batas yang dapat diterima selama periode waktu penyimpanan dan penggunaan, dimana sifat dan karakteristik sama dengan yang dimilikinya pada saat dibuat.

Berdasarkan hasil uji organoleptis sediaan lip balm, memiliki tekstur yang bervariasi mulai dari F1 tekstur setengah padat dan sangat halus, F2 tekstur setengah padat dan halus, F3 tekstur yang dihasilkan padat dan agak keras, 
memiliki warna ungu kemerahan dan aroma khas strawberry. Warna yang dihasilkan dari sediaan lip balm yaitu ungu kemerahan, karena kayu secang teroksidasi dan menghasilkan senyawa brazilein yang berwarna merah keunguan. Perbedaan masing-masing formula tersebut dipengaruhi oleh konsentrasi basis beeswax yang digunakan. Semakin tinggi basis yang digunakan maka semakin padat tekstur sediaan yang dihasilkan. Berdasarkan hasil uji stabilitas sediaan, sediaan lip balm yang dibuat telah memenuhi syarat uji stabilitas. Sediaan dikatakan telah memenuhi syarat uji stabilitas karena tidak terdapat adanya perubahan pada tekstur, warna, dan aroma pada sediaan lip balm. Hasil uji organoleptis dapat dilihat pada tabel 3.

Tabel 3. Uji Organoleptis Sediaan Lip Balm Ekstrak Kayu Secang (Caesalpinia sappan L)

\begin{tabular}{|c|c|c|c|}
\hline \multicolumn{4}{|c|}{ Siklus - 0 } \\
\hline Formula & Bentuk & Warna & Aroma \\
\hline Formula I & Semi padat & Ungu kemerahan & Strawberry \\
\hline Formula II & Semi padat & Ungu kemerahan & Strawberry \\
\hline Formula III & Padat & Ungu kemerahan & Strawberry \\
\hline \multicolumn{4}{|c|}{ Siklus -1} \\
\hline Formula & Bentuk & Warna & Aroma \\
\hline Formula I & Semi padat & Ungu kemerahan & Strawberry \\
\hline Formula II & Semi padat & Ungu kemerahan & Strawberry \\
\hline Formula III & padat & Ungu kemerahan & Strawberry \\
\hline \multicolumn{4}{|c|}{ Siklus - 2 } \\
\hline Formula & Bentuk & Warna & Aroma \\
\hline Formula I & Semi padat & Ungu kemerahan & Strawberry \\
\hline Formula II & Semi padat & Ungu kemerahan & Strawberry \\
\hline Formula III & padat & Ungu kemerahan & Strawberry \\
\hline \multicolumn{4}{|c|}{ Siklus $-\mathbf{3}$} \\
\hline Formula & Bentuk & Warna & Aroma \\
\hline Formula I & Semi padat & Ungu kemerahan & Strawberry \\
\hline Formula II & Semi padat & Ungu kemerahan & Strawberry \\
\hline Formula III & padat & Ungu kemerahan & Strawberry \\
\hline \multicolumn{4}{|c|}{ Siklus - 4} \\
\hline Formula & Bentuk & Warna & Aroma \\
\hline Formula I & Semi padat & Ungu kemerahan & Strawberry \\
\hline Formula II & Semi padat & Ungu kemerahan & Strawberry \\
\hline Formula III & padat & Ungu kemerahan & Strawberry \\
\hline \multicolumn{4}{|c|}{ Siklus - 5 } \\
\hline Formula & Bentuk & Warna & Aroma \\
\hline Formula I & Semi padat & Ungu kemerahan & Strawberry \\
\hline Formula II & Semi padat & Ungu kemerahan & Strawberry \\
\hline Formula III & padat & Ungu kemerahan & Strawberry \\
\hline \multicolumn{4}{|c|}{ Siklus - 6} \\
\hline Formula & Bentuk & Warna & Aroma \\
\hline Formula I & Semi padat & Ungu kemerahan & Strawberry \\
\hline Formula II & Semi padat & Ungu kemerahan & Strawberry \\
\hline Formula III & padat & Ungu kemerahan & Strawberry \\
\hline
\end{tabular}

Sediaan lip balm dikatakan baik apabila sediaan memiliki pH fisiologis kulit bibir yaitu kurang lebih 4 [13]. Sediaan lip balm Formula II dan III memiliki pH 4 dapat dikatakan baik karena sesuai dengan $\mathrm{pH}$ fisiologis kulit bibir yaitu kurang dari 4 [13]. Menurut Tranggono, 2007 sediaan lip balm dikatakan baik apabila memiliki $\mathrm{pH}$ dan termasuk pada rentang $\mathrm{pH}$ bibir yaitu 4,5-6,5 [2]. Sediaan lip balm Formula I memiliki nilai pH 5 dan dapat dikatakan bahwa pH tersebut baik dan aman digunakan karena termasuk pada rentang $\mathrm{pH}$ bibir 4,5-6,5 [2]. Hal ini menunjukkan bahwa sediaan lip balm yang dibuat aman dan tidak menyebabkan iritasi pada bibir. Semakin alkalis atau semakin asam bahan yang mengenai kulit, maka kulit menjadi kering dan pecahpecah. Jika $\mathrm{pH}$ dibawah standar maka timbul seperti rasa gatal, dan apabila $\mathrm{pH}$ diatas standar akan menyebabkan bibir panas. Hasil uji pH sediaan menunjukkan bahwa sediaan yang dibuat memenuhi syarat uji $\mathrm{pH}$ sediaan lip balm. Hasil uji pH dapat dilihat pada tabel 4.

Uji homogenitas bertujuan untuk mengetahui apakah pencampuran masing-masing komponen bahan dalam pembuatan lip balm ini telah merata atau tidak dan melihat sediaan lip balm tersebut homogen atau terdapat butiran kasar. homogenitas merupakan salah satu faktor yang mempengaruhi kualitas dari sediaan lip balm. 
Tabel 4. Uji pH Sediaan Lip Balm Ekstrak Kayu Secang (Caesalpinia sappan L)

\begin{tabular}{|c|c|c|c|c|}
\hline \multirow{2}{*}{ Siklus } & \multirow{2}{*}{ Spesifikasi } & \multicolumn{3}{|c|}{ pH } \\
\hline & & Formula I & Formula II & Formula III \\
\hline Siklus -0 & & 5 & 4 & 4 \\
\hline Siklus - 1 & & 5 & 4 & 4 \\
\hline Siklus - 2 & $4,5-6,5[2]$ & 5 & 4 & 4 \\
\hline Siklus -3 & & 5 & 4 & 4 \\
\hline Siklus -4 & & 5 & 4 & 4 \\
\hline Siklus -5 & & 5 & 4 & 4 \\
\hline Siklus - 6 & & 5 & 4 & 4 \\
\hline
\end{tabular}

Tabel 5. Uji Homogenitas Sediaan Lip Balm Ekstrak Kayu Secang (Caesalpinia sappan L)

\begin{tabular}{ccrrr}
\hline Siklus & Spesifikasi & \multicolumn{3}{c}{ Homogenitas } \\
\cline { 3 - 5 } & & Formula I & Formula II & Formula III \\
\hline Siklus -0 & & $(-)$ & $(-)$ & $(-)$ \\
Siklus -1 & Tidak terlihat butiran kasar & $(-)$ & $(-)$ & $(-)$ \\
Siklus - & & $(-)$ & $(-)$ & $(-)$ \\
Siklus - & & $(-)$ & $(-)$ & $(-)$ \\
Siklus -4 & & $(-)$ & $(-)$ & $(-)$ \\
Siklus - & & $(-)$ & $(-)$ & $(-)$ \\
Siklus - 6 & & $(-)$ & $(-)$ & $(-)$ \\
\hline
\end{tabular}

Keterangan

$(-) \quad=$ Menunjukkan tidak terlihat butiran kasar pada sediaan (Homogen)

$(+) \quad=$ Menunjukkan adanya butiran kasar pada sediaan (Tidak homogen)

Hasil uji homogenitas sebelum stabilitas dipercepat tidak menunjukkan adanya partikel kasar pada masingmasing formula 1, formula 2, dan formula 3, dapat diartikan bahwa ketiga formula tersebut homogen. Hasil uji homogenitas dapat dilihat pada tabel 5. Hasil uji homogenitas setelah dilakukan uji stabilitas dipercepat menggunakan metode cycling test menggunakan 6 siklus, sediaan lip balm pada formula 1, formula 2, dan formula 3 didapatkan hasil sediaan homogen. Sediaan dikatakan homogen apabila tidak terlihat adanya butir-butir kasar [8]. Berdasarkan hasil pengamatan tersebut dapat dikatakan bahwa sediaan lip balm yang dibuat memenuhi syarat uji homogenitas sediaan dan stabil dalam penyimpanan.Uji daya sebar dilakukan untuk mengetahui sejauh mana sediaan lip balm dapat menyebar ketika di aplikasikan pada kulit. Daya sebar yang baik dapat menjamin pemerataan sediaan lip balm saat diaplikasikan pada bibir. Hasil uji daya sebar sebelum dilakukan uji stabilitas dipercepat yaitu $5,27 \mathrm{~cm}$ pada Formula I, 5,49 $\mathrm{cm}$ pada Formula II, hasil daya sebar yang di hasilkan Formula I dan Formula II dapat dikatakan memenuhi syarat uji daya sebar. Sediaan yang memenuhi uji daya sebar harus memiliki diameter berkisar antara $5-7 \mathrm{~cm}$. Hasil uji daya sebar dapat dilihat pada tabel 6.

Formula I dengan konsentrasi beeswax 5\% dan Formula II dengan konsentrasi beeswax 10\% menghasilkan sediaan lip balm dengan tekstur semi padat dan tidak terlalu keras sehingga sediaan lip balm dapat menyebar dengan mudah dan merata dengan mendapatkan hasil daya sebar yang semakin tinggi. Pada Formula III nilai daya sebar yang di dapat yaitu 4,04 cm, dapat dikatakan sediaan tidak memenuhi syarat uji daya sebar, karena sediaan yang memenuhi uji daya sebar harus memiliki diameter berkisar antara 5-7 cm. Formula III dengan konsentrasi beeswax $15 \%$ menghasilkan sediaan lip balm dengan tekstur padat dan agak mengeras, sehingga sediaan lip balm tidak dapat menyebar dengan mudah dan merata nilai daya sebar yang dihasilkan juga semakin rendah. Hasil daya sebar pada setiap formula berbeda dimana semakin tinggi konsentrasi beeswax yang digunakan semakin rendah nilai daya sebar yang di dapat karena tekstur sediaan lip balm padat dan mengeras sehingga tidak bisa menyebar secara mudah dan merata. Jika konsentrasi beeswax yang digunakan rendah maka semakin tinggi nilai daya sebar yang di dapat karena tekstur sediaan semi padat sehingga sediaan mudah menyebar dengan mudah dan merata.

Daya lekat yang baik ditandai dengan mudah melekatnya sediaan pada daerah yang diaplikasikan.Semakin besar nilai respon daya lekat yang dihasilkan berarti waktu yang dibutuhkan oleh lip balm untuk dapat melekat pada bibir semakin banyak. Begitu pula sebalikanya,semakin kecil nilai daya lekat, maka semakin sedikit waktu yang dibutuhkan sediaan lip balm untuk melekat pada bibir. Dari hasil pemeriksaan daya lekat sediaan, sediaan lip balm yang 
dibuat dikatakan baik. Hasil uji daya sebar dapat dilihat pada tabel 7.

Hasil daya lekat sebelum dilakukan stabilitas pada ketiga formula yaitu Formula I (18,54 detik), Formula II (23,81 detik), dan Formula III (29,51 detik). Persyaratan untuk daya lekat lip balm bila daya lekat lebih dari 4 detik. Hasil daya lekat sesudah stabilitas fisik dipercepat dengan metode cycling test menggunakan 6 siklus yaitu 19,29 detik pada Formula I, 23,99 detik pada Formula II, dan 29,90 detik pada Formula III. Dari hasil ketiga formula terdapat perbedaan pada nilai daya lekat yang dihasilkan, semakin tinggi konsentrasi beeswax yang digunakan semakin tinggi juga nilai daya lekat yang dihasilkan, semakin rendah konsentrasi beeswax yang digunakan semakin rendah juga nilai daya lekat yang dihasilkan. Persyaratan daya lekat yang baik bila daya lekat lebih dari 4 detik.

Tabel 6. Uji Daya Sebar Sediaan Lip Balm Ekstrak Kayu Secang (Caesalpinia sappan L)

\begin{tabular}{ccccc}
\hline \multirow{2}{*}{ Siklus } & \multirow{2}{*}{ Spesifikasi } & \multicolumn{3}{c}{ Daya Sebar (cm) } \\
\cline { 3 - 5 } & & Formula I & Formula II & Formula III \\
\hline Siklus -0 & & 5,27 & 5,49 & 4,04 \\
Siklus -1 & $5-7 \mathrm{~cm}$ & 5,4 & 5,23 & 3,37 \\
Siklus -2 & & 5,67 & 5,43 & 3,85 \\
Siklus -3 & & 5,71 & 5,9 & 4 \\
Siklus -4 & & 5,65 & 5,37 & 4,07 \\
Siklus -5 & & 5,75 & 5,35 & 3,98 \\
Siklus - & & 6,57 & 5,65 & 4,48 \\
\hline
\end{tabular}

\begin{tabular}{ccccc}
\hline \multicolumn{5}{c}{ Tabel 7. Uji Daya Lekat Sediaan Lip Balm Ekstrak Kayu Secang (Caesalpinia sappan L) } \\
\cline { 3 - 5 } Siklus & \multirow{2}{*}{ Spesifikasi } & Formula I & Daya Lekat & Formula II \\
\hline Siklus -0 & & 18,54 & 23,81 & 29,51 \\
Siklus - & & 18,87 & 23,55 & 29,13 \\
Siklus - & Lebih dari 4 & 19,04 & 24,27 & 29,18 \\
Siklus - & detik & 18,99 & 24,78 & 30,52 \\
Siklus - & & 19,65 & 24,51 & 30,21 \\
Siklus - & & 18,91 & 24,84 & 29,01 \\
Siklus - 6 & & 19,29 & 23,99 & 29,90 \\
\hline
\end{tabular}

Hasil uji iritasi dari pemakaian sediaan lip balm Formula

I, panelis tidak menunjukkan adanya tanda iritasi seperti kemerahan, gatal-gatal, ataupun bengkak, karena sediaan lip balm Formula I memiliki nilai $\mathrm{pH} 5$ yang sesuai dengan $\mathrm{pH}$ kulit 4,5-6,5 [2] sehingga aman untuk digunakan dan tidak menimbulkan iritasi. Hasil uji iritasi dari pemakaian sediaan lip balm Formula II dan Formula III, panelis tidak menunjukkan adanya tanda iritasi seperti kemerahan, gatalgatal, ataupun bengkak, sediaan lip balm Formula II dan Formula III memiliki nilai $\mathrm{pH} 4$ tetapi pada uji iritasi panelis tidak mendapat tanda-tanda iritasi karena menurut Balsam [13] $\mathrm{pH}$ fisiologis kulit bibir yaitu kurang lebih 4 sehingga sediaan lip balm aman untuk digunakan. Hasil uji iritasi dapat dilihat pada tabel 8.

Pengujian dilakukan dengan membandingkan keadaan bibir sebelum dan sesudah pemakaian sediaan dengan nilai parameter kelembaban. Semua panelis diukur terlebih dahulu kondisi kelembaban bibir awal menggunakan alat skin analyzer. Sediaan lip balm dioleskan pada bibir panelis lalu dibiarkan hingga 12 jam, dan pengecekan kondisi kelembaban bibir dilakukan selama 12 jam sekali sebelum dan sesudah pemakaian lip balm. Pengukuran kondisi bibir dilakukan setiap hari selama 7 hari dengan pemberian sediaan lip balm setiap hari secara rutin pagi dan sore hari. Uji kelembaban digunakan untuk melihat perbandingan hasil dari kelembaban pada Formula I, Formula II, dan Formula III. Kategori parameter dari bibir dapat digolongkan kering (0\%-45\%), normal atau lembab (46\%-55\%), sangat lembab (56\%-100\%) [14]. Hasil uji kelembaban dapat dilihat pada tabel 9. 
Tabel 8. Uji Iritasi Sediaan Lip Balm Ekstrak Kayu Secang (Caesalpinia sappan L)

\begin{tabular}{|c|c|c|c|c|c|c|c|c|c|c|}
\hline \multirow{2}{*}{ Reaksi } & \multicolumn{10}{|c|}{ Panelis } \\
\hline & 1 & 2 & 3 & 4 & 5 & 6 & 7 & 8 & 9 & 10 \\
\hline Eritema & - & - & - & - & - & - & - & - & - & - \\
\hline Eritema dan papula & - & - & - & - & - & - & - & - & - & - \\
\hline Eritema,papula,dan vesikula & - & - & - & - & - & - & - & - & - & - \\
\hline Eritema dan vesikula & - & - & - & - & - & - & - & - & - & - \\
\hline \multicolumn{11}{|l|}{ Keterangan } \\
\hline : Tidak ada reaksi & & & & & & & & & & \\
\hline : Eritema & & & & & & & & & & \\
\hline : Eritema dan papula & & & & & & & & & & \\
\hline$++\quad$ : Eritema dan vesikula & & & & & & & & & & \\
\hline : Eritema, papula, dan vesikula & & & & & & & & & & \\
\hline
\end{tabular}

Tabel 9. Uji Kelembaban Sediaan Lip Balm Ekstrak Kayu Secang (Caesalpinia sappan L)

\begin{tabular}{|c|c|c|c|c|c|c|c|c|c|c|c|c|c|c|c|c|c|}
\hline \multirow[t]{2}{*}{ No } & \multirow[t]{2}{*}{ Panelis } & \multirow{2}{*}{$\begin{array}{c}\text { Kondisi } \\
\text { awal }\end{array}$} & \multicolumn{14}{|c|}{$\begin{array}{l}\text { Waktu perawatan } \\
\text { Tiap 12 Jam }\end{array}$} & \multirow{2}{*}{$\begin{array}{c}\text { Persen } \\
\text { Peningkatan } \\
\text { Kelembaban }\end{array}$} \\
\hline & & & 12 & 24 & 36 & 48 & 60 & 72 & 84 & 96 & 108 & 120 & 132 & 144 & 156 & 168 & \\
\hline \multirow[t]{3}{*}{$\mathrm{F} 1$} & 1 & 23 & 26 & 28 & 30 & 32 & 35 & 36 & 37 & 39 & 41 & 44 & 45 & 52 & 52,5 & 66 & $186 \%$ \\
\hline & 2 & 13 & 13,9 & 15 & 20 & 24 & 26 & 29 & 32 & 33 & 34 & 40 & 45 & 46 & 55 & 66 & $407 \%$ \\
\hline & 3 & 13 & 19 & 22 & 25,7 & 29 & 35 & 42 & 45 & 48 & 51 & 57 & 59 & 65 & 67 & 70 & $438 \%$ \\
\hline \multicolumn{2}{|c|}{ Rata-rata } & 16,3 & 19,6 & 21,6 & 25,2 & 28,3 & 32 & 35,6 & 38 & 40 & 42 & 47 & 49,6 & 54 & 58 & 67 & $311 \%$ \\
\hline \multirow[t]{3}{*}{$\mathrm{F} 2$} & 1 & 15 & 21 & 28 & 35 & 38 & 43 & 44 & 46 & 47 & 49 & 50 & 52 & 58 & 60 & 87 & $480 \%$ \\
\hline & 2 & 14 & 15 & 19 & 23 & 27 & 28 & 30 & 36 & 38 & 40 & 41 & 42 & 43 & 45 & 46 & $228 \%$ \\
\hline & 3 & 15 & 19 & 19,2 & 25 & 27 & 30 & 34 & 36 & 37 & 39 & 40 & 41 & 45 & 47 & 50 & $233 \%$ \\
\hline \multicolumn{2}{|c|}{ Rata-rata } & 14,6 & 18,3 & 18,7 & 27,6 & 30,6 & 33,6 & 36 & 39 & 41 & 43 & 44 & 45 & 49 & 51 & 61 & $317 \%$ \\
\hline \multirow[t]{4}{*}{ F3 } & 1 & 11 & 17 & 17,8 & 19 & 24 & 28 & 30 & 32 & 33 & 34 & 35 & 36 & 42 & 46 & 52 & $372 \%$ \\
\hline & 2 & 15 & 23 & 27 & 29 & 30 & 37 & 40 & 41 & 42 & 45 & 47 & 53 & 54 & 65 & 71 & $373 \%$ \\
\hline & 3 & 13 & 14 & 19 & 24 & 26 & 27 & 30 & 31 & 32 & 33 & 36 & 53 & 56 & 57 & 61 & $369 \%$ \\
\hline & ta-rata & 13 & 18 & 21 & 24 & 27 & 27,3 & 33 & 35 & 36 & 37 & 39 & 47 & 51 & 56 & 61 & $369 \%$ \\
\hline
\end{tabular}

Hasil dari data uji kelembaban sediaan lip balm ekstrak kayu secang yang didapat selama 7 hari yaitu pada Formula I terdapat rata-rata persen peningkatan kelembaban 311\%, pada Formula II terdapat rata-rata persen peningkatan kelembaban $317 \%$, pada Formula III terdapat rata-rata persen peningkatan kelembaban 369\%. Dari ketiga sediaan lip balm dengan berbagai variasi beeswax dapat meningkatkan kelembaban bibir yang dilakukan selama 7 hari tiap 12 jam Adanya kenaikan kadar kelembaban selama 7 hari kemungkinan besar bisa dari pengaruh ekstrak kayu secang, karena pada penelitian sebelumnya telah menunjukkan bahwa aktivitas antioksidan dari ekstrak kayu secang dengan metode DPPH mempunyai nilai IC50 sebesar 1,2978 mg/mL itu termasuk antioksidan sangat aktif, karena aktivitas antioksidan digolongkan sangat aktif jika nilai IC50 kurang dari $50 \mathrm{ppm}$. Dengan adanya antioksidan yang terdapat pada kayu secang dapat berfungsi sebagai penangkap efek buruk dari radikal bebas yang menyebabkan kerusakan kulit seperti kering, kusam, pecah-pecah, dan tidak lembab.

\section{Kesimpulan}

Kesimpulan yang dapat diambil dari hasil penelitian studi formulasi sediaan lip balm ekstrak kayu secang (Caesalpinia sappan L.) dengan variasi beeswax diantaranya adalah formulasi dari sediaan lip balm ekstrak kayu secang
(Caesalpinia sappan L.) dengan variasi beeswax yaitu menggunakan ekstrak kayu secang sebagai zat aktif, beeswax sebagai basis, setil alkohol sebagai pengental, kaolin sebagai pemberi tekstur, metil paraben sebagai pengawet, olive oil sebagai emolien dan essence strawberry sebagai pengaroma.

Stabilitas fisik yang dihasilkan dari formula 1 dengan konsentrasi beeswax 5\% dan formula 2 pada konsentrasi beeswax $10 \%$ telah memenuhi stabilitas fisik yang baik, dimana sediaan lip balm menghasilkan tekstur warna, aroma, memiliki nilai daya lekat dan daya sebar yang baik, $\mathrm{pH}$ rentang terhadap $\mathrm{pH}$ bibir, tidak mengiritasi, sediaan homogen, dan stabil selama penyimpanan. Pada formula 3 tekstur yang dihasilkan padat sehingga tidak sesuai spesifikasi yang diharapkan, daya sebar tidak sesuai dengan spesifikasi dengan nilai dibawah 5 , uji $\mathrm{pH}$, daya lekat, homogenitas, uji iritasi sesuai dengan spesifikasi, stabil dalam penyimpanan.

Perbedaan konsentrasi beeswax yang diformulasikan pada sediaan lip balm memberikan pengaruh pada tekstur sediaan, semakin tinggi konsentrasi yang digunakan maka semakin padat tekstur pada sediaan. Konsentrasi beeswax 5\% dan $10 \%$ menghasilkan sediaan yang bagus dengan tekstur semi padat dan tidak mengeras. 


\section{Daftar Pustaka}

[1] Mitsui, T. (1997). New Cosmetic Science. Amsterdam: Elsveir Science. Hal. 3, 13, 121, 386.

[2] Tranggono dan Latifah,2007. Buku Pegangan Ilmu Pengetahuan Kosmetik.Jakarta:Gramedia Pustaka Utama.

[3] Balsam, M.S., dan Sagarin, E. (2008). Cosmetics Science and Technology. Second Edition. USA: Wiley Interscience Publication. Halaman 43, 46.

[4] Madans, A., Katie, P., Christine, P., Shaily, P. (2012). Ithaca Got Your Lips Chapped: A Performance Analysis of Lip Balm. BEE 4530. Halaman 4-5.

[5] Trookman, N.S., Ronald, L., Rosanne, F., Rahul, M., Vincent, G. (2009). Clinical Assesment of a Combination Lip Treatment to Restore Moisturazation and Fullness. The Journal of Clinical Aesthetic Dermatology. 2 (12). Hal : 4445.

[6] Handoyo Lioni Ellis, 2014.Dahsyatnya Kulit Buah dan Tanaman Pembasmi Berbagai Penyakit. Jakarta Timur : Padi.
[7] Harborne, J.B. 1987. Metode Fitokimia Penuntun Cara Modern Menganalisis Tumbuhan. Penerbit ITB. Bandung.

[8] Departemen Kesehatan Republik Indonesia.1985.Formularium Kosmetika.Ditjen POM RI. Jakarta.

[9] Kristanti, Alfinda Novi. 2008. Buku Ajar Fitokimia. Surabaya: Universitas Airlangga Press.

[10] Dirjen POM.(1995). Farmakope Indonesia Edisi IV.Jakarta : Depkes RI.

[11] Voight, R., 1994, Buku Pengantar Teknologi Farmasi, 572574, diterjemahkan oleh Soedani, N., Edisi V, Yogyakarta, Universitas Gadjah Mada Press.

[12] Cahyadi, W. 2009. Bahan Tambahan Pangan. Jakarta: Bumi Aksara. Halaman 63-74.

[13] Balsam, M.S,.(1972), Cosmetic Science and Technology, Edisi Kedua.New York:John Willy and Son Inc

[14] Wasitaatmadja, Sjarif M. (1997). Penuntun Ilmu Kosmetik Medik. Jakarta: UI Press, 36-37; 122-124. 